\title{
Evidence for direct inhibition of ovarian function by prolactin
}

\author{
A. S. McNeilly, Anna Glasier, Julie Jonassen and P. W. Howie*
}

M.R.C. Unit of Reproductive Biology and Department of Obstetrics \& Gynaecology, University of Edinburgh Centre for Reproductive Biology, 37 Chalmers Street, Edinburgh EH3 9EW, U.K.

\section{Introduction}

There is no doubt that in breast-feeding women, suckling with its associated hyperprolactinaemia prevents the resumption of ovarian activity for prolonged periods (see McNeilly, 1979). The extent of this suppression varies greatly among species but in all for which there are adequate data it appears to depend critically upon the intensity of the suckling stimulus (Lamming, 1978). Our recent data from women show that in the pattern of suckling, frequency and duration, throughout the day, are both key factors in maintaining the elevation of basal levels of prolactin associated with lactation (McNeilly, Howie \& Houston, 1980a; Howie \& McNeilly, 1982). Suckling also releases large quantities of prolactin, maintaining a physiological hyperprolactinaemic state which is directly associated with the duration of lactational amenorrhoea (Delvoye, Badawi, Demaegd \& Robyn, 1978; Duchen \& McNeilly, 1980). The question remains, how does suckling suppress ovarian activity?

The levels of prolactin in blood during peak lactation appear to be many times the requirement for production of milk. It therefore becomes pertinent to ask whether this prolactin is released solely to stimulate milk production or whether it is involved directly in the suppression of ovarian activity. If there is a direct involvement then there are two loci for this action; an effect at the hypothalamic-pituitary level or a direct effect on the ovary. While the former has received some attention (see McNeilly, 1979, 1980a), relatively little information is available (for species other than the rat) on whether or how prolactin might act on the ovary and, in particular, how high levels might interfere or block follicular development during lactation (McNeilly, $1980 \mathrm{~b}$ ). The purpose of this paper is to review the evidence for a direct action of prolactin on the ovary in the context of the effects of prolactin in the control of normal ovarian cyclicity.

\section{Prolactin and the normal ovarian cycle}

While this is not the place to present an exhaustive review of the literature pertaining to the role of prolactin in the normal ovarian cycle it is necessary to discuss briefly how prolactin is involved so that this may be set against any directly inhibitory role associated with hyperprolactinaemic states.

\section{Changes in blood concentrations of prolactin in ovarian cycles}

In the majority of species studied adequately so far prolactin levels change little during the luteal phase of the cycle but increase around the time of ovulation in association with the

\footnotetext{
* Present address: Department of Obstetrics \& Gynaecology, Ninewells Hospital and Medical School, University of Dundee, U.K.
} 
increasing levels of oestrogens at this time (see McNeilly, 1980a; Cowie, Forsyth \& Hart, 1980). In the rat, however, the corpus luteum of pseudopregnancy or pregnancy will not function unless prolactin levels are sustained after ovulation (see Richards, 1980). In primates no clear-cut rise in blood levels of prolactin can be seen although there is some evidence of a small increase around the time of the ovulatory surge of LH in women (see McNeilly, 1980a).

\section{Prolactin and follicular growth and development}

While there is evidence for a requirement for prolactin in maintaining growth and/or development of follicles, the mechanisms are poorly understood. Studies in which blood levels of prolactin have been suppressed pharmacologically with bromocriptine (sheep: Niswender, 1974; cow: Hoffmann et al., 1974; women: Besser, Parke, Edwards, Forsyth \& McNeilly, 1972), ergocornine (ewes: Louw, Lishman, Botha \& Baumgartner, 1974) or with antiserum to prolactin (cows: Hoffmann et al., 1974) suggest that only minimal amounts of prolactin are needed for normal follicular growth. It does appear that some prolactin is necessary for steroidogenesis, in women at least, because human granulosa cells grown in vitro in the absence of prolactin fail to secrete progesterone even in the presence of adequate amounts of gonadotrophin (McNatty, Sawers \& McNeilly, 1974; McNatty, Bennie, Hunter \& McNeilly, 1975).

Whether changes in the blood level of prolactin, provided they are within the normal range, are of relevance to gonadal function may be in doubt. In follicular fluid of developing human follicles prolactin concentrations change in a discrete pattern during the menstrual cycle independently of the blood level (McNatty et al., 1974). High levels (4-6 times those in serum) are found in follicular fluid during the early follicular phase of the cycle and decrease progressively towards midcycle when an inverse relationship between prolactin and progesterone levels within the follicular fluid is observed. Similar observations have been made for both the sheep (McNatty, 1977) and cow (Henderson, McNeilly \& Swanston, 1982). These results suggest that changes of hormones within the follicle and not necessarily in the blood may be of prime importance for follicular development at least in terms of prolactin. Indeed, more recent studies on granulosa cells suggest that this may well be the case. In the pig the number of prolactin receptors on granulosa cells decrease with increasing size of follicle (Rolland \& Hammond, 1975) a change which appears to be steroid mediated (Hammond \& Krall, 1979) and dependent on the stage of cytodifferentiation (Veldhuis, Klase \& Hammond, 1980). Exposure of granulosa cells from mature follicles to oestradiol in vitro increases the number of prolactin receptors and then prolactin stimulates progesterone secretion, apparently interacting synergistically with oestradiol (Veldhuis \& Hammond, 1980; Veldhuis et al., 1981).

A similar sequence of events appears to occur in the rat. Before ovulation prolactin binding to theca and granulosa cells is low but increases in granulosa cells in response to the preovulatory LH surge (Richards \& Midgley, 1976; Richards et al., 1976; Rao, Richards, Midgley \& Reichert, 1977). In immature female rats that have been hypophysectomized and treated with diethylstilboestrol FSH will increase the number of prolactin receptors on granulosa cells in vivo and in vitro (Wang, Hsueh \& Erickson, 1979). Prolactin alone added to such cells will increase progesterone secretion, decrease $20 \alpha$-hydroxysteroid dehydrogenase activity and secretion of 20a-hydroxypregn-4-en-3-one without affecting oestrogen secretion (Eckstein \& Nimrod, 1979; Wang et al., 1979, 1980).

\section{Prolactin and corpus luteum function}

Over the years confusion has arisen as to the role of prolactin in corpus luteum function. The so-called luteotrophic effect of prolactin has been interpreted by many authors to indicate that prolactin per se will promote steroidogenesis. Failure to demonstrate such an effect after 
prolactin administration during the luteal phase of the cycle in the sheep (Karsch et al., 1971), cow (Smith, McShaw \& Casida, 1957) and pig (Anderson, 1966) and the absence of an effect of lowering prolactin levels with bromocriptine in sheep (Niswender, 1974) and cows (Hoffmann et al., 1974) suggested that prolactin played little or no role in luteal maintenance in these species. On the other hand, a decrease in progesterone secretion from the corpus luteum has been shown for women (Schulz et al., 1976) when prolactin levels are suppressed below normal by bromocriptine treatment. It is also clear that in the sheep (Denamur, Martinet \& Short, 1973), goat (H. L. Buttle, personal communication) and ferret (Murphy, 1979) both LH and prolactin are necessary for maintenance of normal luteal progesterone production after hypophysectomy.

In rats and mice postovulatory increases in plasma prolactin concentrations are essential to induce the functional corpora lutea of pregnancy or pseudopregnancy (Everett, 1961; Dominic, 1966). Mating in the rat is associated with an increased diurnal secretion of prolactin (Smith, Freeman \& Neill, 1975), blockade of which by ergocornine or bromocriptine treatment leads to failure of progesterone secretion and corpus luteum function (Wuttke \& Dohler, 1973).

Prolactin alone will stimulate the secretion of progesterone from the rat corpus luteum (Richards \& Williams, 1976) and is responsible for the induction of luteal LH receptors (Holt, Richards, Midgley \& Reichert, 1976). Within the corpus luteum prolactin enhances the uptake of cholesterol esters (Armstrong, Miller \& Knudsen, 1969), increases cholesterol esterase activity (Behrman, Orczyk, Macdonald \& Greep, 1970; Klemcke \& Brinkley, 1980) and decreases $20 \alpha$-HSD activity, limiting the secretion of $20 \alpha$-dihydroprogesterone (Wiest, Kidwell \& Balogh, 1968). Prolactin also maintains the luteal LH receptor after prostaglandin treatment (Grinwich, Hichens \& Behrman, 1976) or hypophysectomy (Behrman, Grinwich, Hichens \& Macdonald, 1978; Gibori \& Richards, 1978) and stimulates and/or maintains the content of cytosolic oestradiol receptors in luteal cells synergizing with oestradiol to maintain progesterone secretion (Gibori, Richards \& Keyes, 1979). Prolactin-associated accumulation of cholesterol esters has also been demonstrated in rabbit ovarian interstitium (Hilliard, Spies, Lucas \& Sawyer, 1968) and cow ovary (Bartosik, Romanoff, Watson \& Scricco, 1967).

In contrast to its luteotrophic role prolactin may also act as a structural luteolysin in the rat (Malven, 1969) and mouse (Grandison \& Meites, 1972) and is responsible for the final structural demise of the corpora lutea in the normal non-pregnant, non-pseudopregnant cycle (Billeter \& Fluckiger, 1971; Bohnet, Shiu, Grinwich \& Friesen, 1978). No comparable function has been observed in any other species so far studied.

It is clear that prolactin is involved directly at the ovarian level for the growth and development of the follicle and for the maintenance of luteal function in those species investigated. However, the precise mechanisms by which prolactin acts remain to be resolved.

\section{Prolactin and the suppression of ovarian activity post partum}

In a large number of species lactation is associated with a period of ovarian inactivity of varied length (see Lamming, 1978; McNeilly, 1979). This period is related to enhanced prolactin secretion and in women an association between hyperprolactinaemia and lactational amenorrhoea has been demonstrated (Delvoye et al., 1978; Duchen \& McNeilly, 1980; McNeilly et al., 1980a; Howie \& McNeilly, 1982). The sequence of hormonal events associated with the suppression and gradual resumption of ovarian activity, in women in particular, has been reviewed previously (McNeilly, 1979; McNeilly et al., 1980a; Howie \& McNeilly, 1982) and will only be outlined here. During the phase of complete ovarian inactivity prolactin values are elevated, FSH levels are within the normal range while LH concentrations are low. In the early post-partum period the low levels of LH may be associated with a reduced frequency and amplitude of LH pulses (Text-fig. 1; A. Glasier, A. S. McNeilly \& P. W. Howie, unpublished observations) and an absence of positive feedback and enhanced negative feedback effects of 

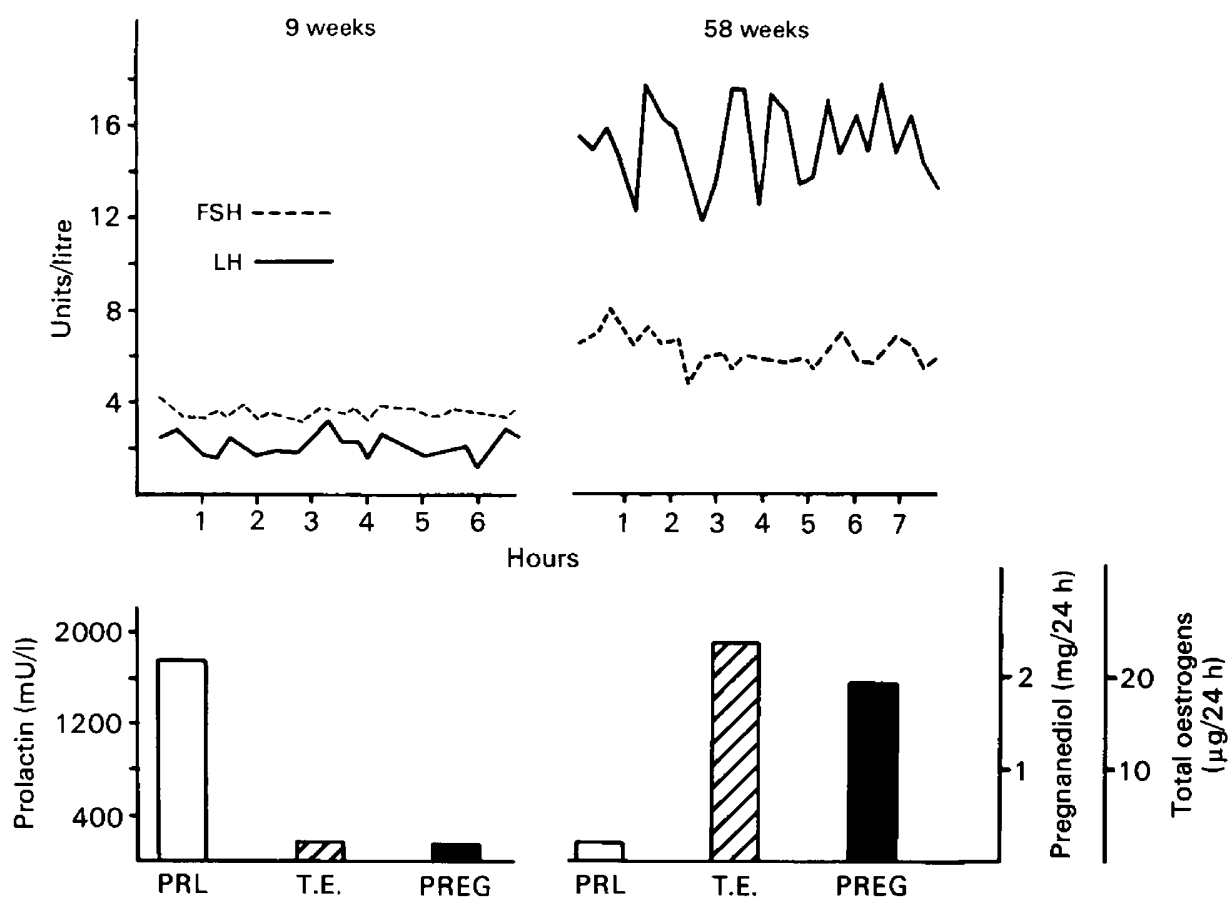

Text-fig. 1. Changes in LH and FSH at 15-min intervals over a 6.5-h period (10:00-14:30 h) in a breast-feeding woman at 9 and 58 weeks post partum. At 9 weeks, ovarian activity, as measured by urinary excretion per $24 \mathrm{~h}$ of total oestrogens (T.E.) and pregnanediol (PREG), was suppressed (T.E. $<10 \mu \mathrm{g} / 24 \mathrm{~h}$; PREG $<0.5 \mathrm{mg} / 24 \mathrm{~h}$ ) while prolactin levels (PRL) over the 6.5-h period and basally were between 2 and 6 times normal. Results are compared to the pattern of LH and FSH secretion in the same woman 8 weeks after weaning at 58 weeks post partum on Day 10 of a normal menstrual cycle. (A. Glasier, A. S. McNeilly \& P. W. Howie, unpublished observations.)

oestrogen on gonadotrophin secretion (Baird, McNeilly, Sawers \& Sharpe, 1979; Glass, Rudd, Lynch \& Butt, 1981). The resumption in ovarian activity occurs as a consequence of a decrease in the suckling stimulus which results in a fall of basal prolactin concentrations and an increase in basal levels and pulsatile release of LH (Text-fig. 1; McNeilly et al., 1980a; Howie \& McNeilly, 1982; A. Glasier, A. S. McNeilly \& P. W. Howie, unpublished observations). However, while lactation continues ovulation is invariably associated with prolonged follicular phases and deficient corpora lutea secreting inadequate amounts of progesterone. Only when lactation ceases completely or when prolactin levels return to normal are ovulatory cycles associated routinely with normal corpus luteum function. A similar situation and sequence of events occurs during the re-establishment of ovarian cyclicity during lactation in the cow (e.g. Schams et al., 1978; Stevenson \& Britt, 1979; Carruthers \& Hafs, 1980; Webb, Lamming, Haynes \& Foxcroft, 1980), sheep (Fitzgerald \& Cunningham, 1981; Wright, Geytenbeck, Clarke \& Findlay, 1981) and pig (Stevenson, Cox \& Britt, 1981). Whether the high levels of prolactin or the suckling stimulus alone or together are responsible for the suppression of LH secretion during lactation has been discussed previously (McNeilly, 1980a). What is of interest is to determine whether the high levels of prolactin per se might interfere with follicular development, ovulation or corpus luteum function by a direct action on the ovary. In $40 \%$ of the women investigated during lactation when ovarian activity was fully suppressed, basal concentrations and pulsatile secretion of $\mathrm{LH}$ had increased to levels indistinguishable from those 
seen when follicular development and ovulation had returned (Text-fig. 2). The most significant difference between these two situations, i.e. similar LH levels in the absence and then the presence of follicular development was the much greater plasma concentration of prolactin in the former compared to the latter. Nevertheless even though follicular growth and development and ovulation did occur, the resulting corpus luteum remained inadequate until prolactin levels returned to normal. These results suggest that during lactation in women elevated levels of prolactin can interfere directly at the ovarian level to prevent the normal action of LH thereby inhibiting follicular growth. Even when this does occur the resulting corpus luteum did not appear to have gained its normal ability to secrete progesterone. Deficient corpora lutea could arise either from a direct inhibitory action of high concentration of prolactin on the corpus luteum itself or because the corpus luteum was formed from a follicle inadequately primed before ovulation.

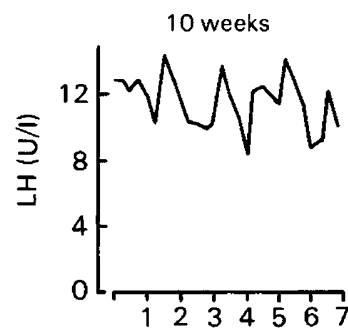

20 weeks

42 weeks
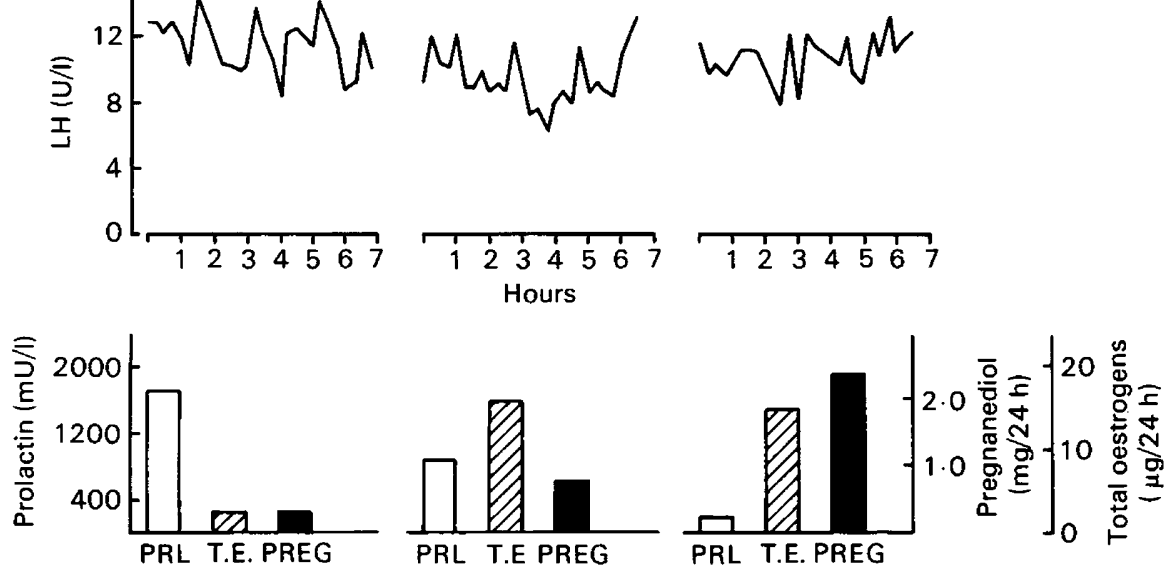

Text-fig. 2. Changes in LH over a 6.5-h period (10:00-14:30 h) in a breast-feeding woman when fully breast feeding with no ovarian activity at 10 weeks, on Day 10 of a menstrual cycle with a deficient corpus luteum at 20 weeks post partum while partly breast feeding and at Day 10 of a normal menstrual cycle at 42 weeks post partum when the baby was fully weaned. PRL $=$ prolactin; T.E. = total oestrogens; PREG = pregnanediol. (A. Glasier, A. S. McNeilly \& P. W. Howie, unpublished observations.)

\section{Hyperprolactinaemia and the corpus luteum}

Several lines of evidence suggest that high levels of prolactin do not interfere with steroidogenesis in the corpus luteum. In the rat the corpus luteum of pregnancy and pseudopregnancy is dependent on prolactin until Day 8 and will not function unless prolactin levels remain elevated during this time (e.g. Garris \& Rothchild, 1980). In hysterectomized sheep there is no change in progesterone secretion from the persistent corpus luteum, even in anoestrus (Baird, Land, Scaramuzzi \& Wheeler, 1976) when prolactin levels are elevated (Walton, McNeilly, McNeilly \& Cunningham, 1977). Similarly, corpora lutea formed after ovulation had been induced by pulsed injections of LH in anoestrous ewes secreted normal levels of progesterone (McNeilly, O'Connell \& Baird, 1980b). In dairy cows, normal luteal function occurs after ovulation in spite of elevated levels of prolactin (Peters, Vyvoda \& Lamming, 1979; Carruthers \& Hafs, 1980), while in monkeys with lesions of the arcuate nucleus and associated hyperprolactinaemia, corpus luteum function was normal after ovulation induction with pulsed injections of LH-RH (Knobil, Plant, Wildt, Belchetz \& Marshall, 1980). While pathological 
hyperprolactinaemia in women with ovulatory menstrual cycles may be associated with short or deficient luteal phases (Seppala, Hirvonen \& Ranta, 1976; Muhlenstedt, Wuttke \& Schneider, 1977), this is not necessarily the case (Sarris et al., 1978). Indeed, when hyperprolactinaemia is induced by pharmacological agents in the luteal phase of the menstrual cycle (TRH: Jewelewicz, Dyrenfurth, Warren, Frantz \& Vande Wiele, 1974; sulpiride: Robyn et al., 1976) or when bromocriptine therapy in hyperprolactinaemic patients is given only during the follicular phase of the cycle thus allowing hyperprolactinaemia during the luteal phase of the cycle (Polatti, Bolis, Ravagni-Probizer, Baruffini \& Cavalleri, 1978; Bennink, 1979), luteal function was within the normal range. The only species in which prolactin has been shown to inhibit progesterone secretion from the corpus luteum is the tammar wallaby. In the tammar, embryonic diapause occurs with development being arrested at the 80 -cell stage, and pregnancy will only continue when the suckling stimulus of the young is removed or diminished (Tyndale-Biscoe \& Hawkins, 1977). This can be prevented by administration of exogenous prolactin (Tyndale-Biscoe, 1979).

It seems probable from these observations that raised levels of prolactin in the luteal phase do not inhibit steroidogenesis and suggest that deficient corpus luteum function in hyperprolactinaemic states arise from ovulation of inadequately primed follicles.

\section{Hyperprolactinaemia and the follicle}

Direct evidence of an inhibitory effect of high levels of prolactin was obtained from in-vitro experiments with human granulosa cells. Increasing amounts of prolactin added to the culture medium inhibited the secretion of progesterone in a dose dependent manner (McNatty et al., 1974). While this mechanism is still not understood a similar inhibition of progesterone secretion, without effect on oestradiol, has been demonstrated in vitro with granulosa cells from small but not large pig follicles (Veldhuis et al., 1980, 1981) and from whole mouse follicles (McNatty, Neal \& Baker, 1976). Increasing levels of prolactin stimulate progesterone secretion in rat granulosa cells in vitro by a dose-related manner, and this is associated with dose-related decrease in oestradiol secretion (Wang et al., 1980). Prolactin can suppress both FSH- and LH-induced increases in oestradiol production without affecting progesterone production, suggesting that prolactin inhibits at a site distal to the gonadotrophin-induced formation of cAMP, i.e. the effect is specific for aromatase or the oestrogen synthetase system (Wang et al., 1980). Indeed, it has now been shown that high levels of prolactin will block FSH induction of aromatase in this system (Dorrington \& Gore-Langton, 1981).

What might be the consequences of these observations? It is clear that oestradiol is a key factor in the development of the follicle and in particular in the growth and differentiation of granulosa cells (Richards, 1980). Thus any suppression of oestrogen secretion would lead to decreased numbers of granulosa cells and since there is little or no mitosis of these cells once transformed into granulosa lutein cells (Diekman, O'Callaghan, Nett \& Niswender, 1978) any decrease in numbers within the follicle would lead to decreased steroidogenic potential in the corpus luteum, i.e. the deficient corpus luteum. McNatty (1979) has shown that raised concentrations of prolactin in plasma and human ovarian follicular fluid were associated with a reduced number of granulosa cells with an inadequate ability to produce steroids and a marked reduction in the values of circulating oestrogens.

While these studies show that raised values of prolactin may inhibit granulosa cell oestrogen secretion by interfering with aromatization of androgens, it is also quite feasible that prolactin might interfere with the production of androgens by the theca interna (Text-fig. 3). The secretion rate of oestradiol from the preovulatory follicle is reduced when sheep are made hyperprolactinaemic by repeated administration of TRH (McNeilly \& Baird, 1977). More recently, with experiments in which prolactin was infused locally into the ovarian arterial circulation, we have demonstrated that this reduction in steroid secretion is not associated with a reduction in the pulsatile secretion of LH (A. S. McNeilly, M. O'Connell \& D. T. Baird, unpublished results). In these experiments the secretion of androstenedione and oestradiol was also inhibited. 
Since androstenedione is thecal in origin and its release is stimulated by $\mathrm{LH}$, it seems probable that high levels of prolactin may also inhibit ovarian follicular steroidogenesis, not only by interfering with aromatase but also by reducing the production by the theca of the androgen precursor necessary for oestrogen production (Text-fig. 3). The results suggest that high levels of prolactin can inhibit follicular development by interfering with steroidogenesis and this could explain, in part at least, the failure of normal luteal function in lactation since it may be presumed that intrafollicular cellular development may be inadequate when ovulation occurs.
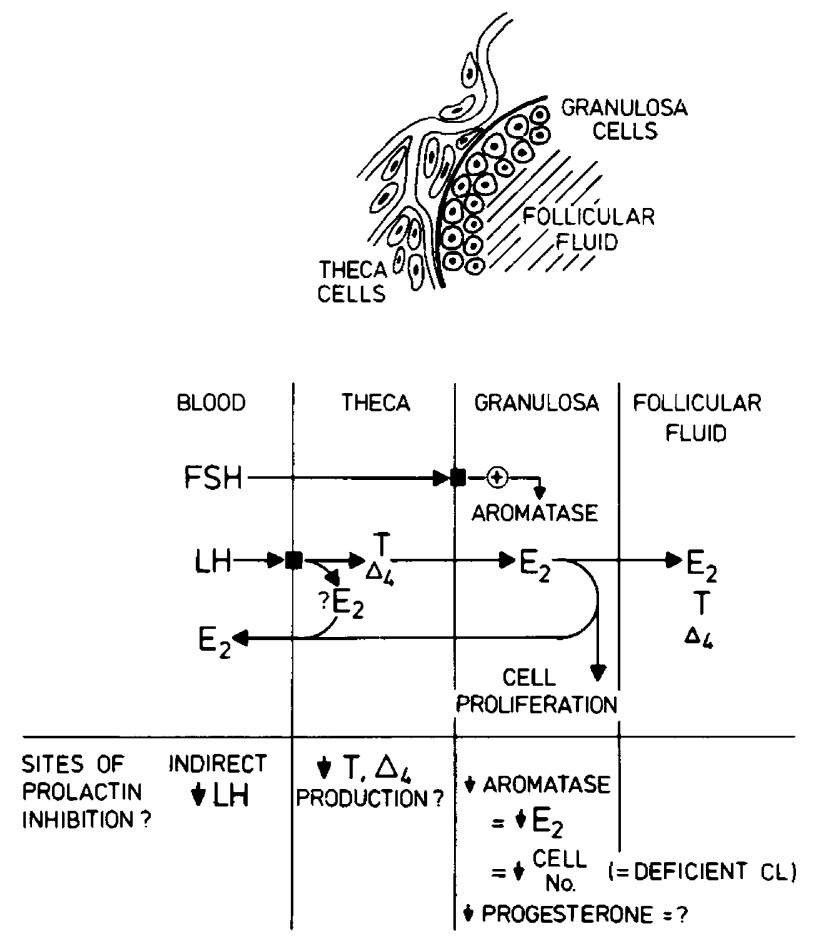

Text-fig. 3. Diagrammatic representation of the control of steroidogenesis within the follicle, indicating the possible sites of inhibition by high levels of prolactin. $T=$ testosterone; $E_{2}=$ oestradiol; $\Delta_{4}=$ androstenedione; $\downarrow=$ decrease or inhibition of synthesis or release; $\oplus=$ stimulation; $\mathbf{0}=$ hormone receptor.

\section{Does prolactin really work like this?}

It seems clear that prolactin may have two divergent actions on the ovary, both stimulatory (permissive) and inhibitory. While there is little evidence to refute the former as a general role in many species, the direct inhibitory role may vary considerably amongst species. In spite of maintained hyperprolactinaemia, normal ovarian activity can and does occur post partum in dairy cows (see Carruthers \& Hafs, 1980), dairy goats (Hart, 1975) and in marmosets (McNeilly, Abbott, Lunn, Chambers \& Hearn, 1981). Ovulation with normal luteal function can be induced in hyperprolactinaemic states by appropriate gonadotrophin treatment in sheep (LH: McNeilly et al., 1980b; PMSG: e.g. Rhind, Robinson, Chesworth \& Crofts, 1980), rhesus monkeys (LH-RH: Knobil et al., 1980) and women (e.g. Kemmann, Gemzell, Beinert, Belling \& Jones, 1977). In women with pathological hyperprolactinaemia, LH-RH-induced release of gonadotrophins will induce normal oestradiol secretion from the ovary (e.g. Lachelin, Abufadil 
\& Yen, 1978; Caro \& Woolf, 1980) and no differences in the amounts of exogenous gonadotrophin required to induce ovulation have been shown (Fraser, Markham \& Shearman, 1978; McGarrigle et al., 1978). However, it may well be that any inhibitory effect of prolactin depends upon the physiological balance within an individual between the concentrations of gonadotrophin and prolactin such that the inhibitory role for prolactin can be overcome by large quantities of gonadotrophin either exogenously administered or endogenously induced by LH-RH treatment.

There is some evidence that, even though cycles may be endocrinologically normal in hyperprolactinaemic states, fertility may be reduced, e.g. in ewes induced to ovulate during lactation (Rhind et al., 1980) and in women with transient hyperprolactinaemia (Fleming, Craig, England, Macnaughton \& Coutts, 1978; Lenton, Brook, Sobowale \& Cooke, 1979). Perhaps some direct interaction between high levels of prolactin within the follicle and oocyte maturation may be implied, in particular since prolactin has been localized within the oocyte (Nolin, 1980) and implicated in oocyte maturation (Baker \& Hunter, 1978).

\section{Conclusions}

While there is abundant evidence that prolactin is involved directly in the normal regulation of ovarian function the precise mechanisms remain to be discovered. There is also clear evidence that in some species abnormally elevated prolactin levels in physiological situations are associated with the inhibition of normal ovarian activity by an action directly on the ovary. Nevertheless, there are exceptions to this and these differences will only be resolved when we understand more fully how prolactin acts normally.

\section{References}

Anderson, L.L. (1966) Pituitary-ovarian-uterine relationships in pigs. J. Reprod. Fert., Suppl. 1, 21-32.

Armstrong, D.T., Miller, L.S. \& Knudsen, K.A. (1969) Regulation of lipid metabolism and progesterone production in rat corpora lutea and ovarian interstitial elements by prolactin and luteinizing hormone. Endocrinology 85, 393-401.

Baird, D.T., Land, R.B., Scaramuzzi, R.J. \& Wheeler, A.G. (1976) Functional assessment of autotransplanted uterus and ovary in the ewe. Proc. $R$. Soc. Lond. B 192, 463-474.

Baird, D.T., McNeilly, A.S., Sawers, R.S. \& Sharpe, R.M. (1979) Failure of estrogen induced discharge of luteinizing hormone in lactating women. $J$. clin. Endocr. Metab. 49, 500-509.

Baker, T.G. \& Hunter, R.H.F. (1978) Interrelationships between the oocyte and somatic cells within the Graafian Follicle of mammals. Annls Biol. anim. Biochim. Biophys. 18, 419-426.

Bartosik, D., Romanoff, E.B., Watson, D.J. \& Scricco, E. (1967) Luteotropic effects of prolactin in the bovine ovary. Endocrinology 81, 185-194.

Behrman, H.R., Orczyk, G.P., Macdonald, G.J. \& Greep, R.O. (1970) Prolactin induction of enzymes controlling luteal cholesterol ester turnover. Endocrinology 37, 1251-1256.

Behrman, H.R., Grinwich, D.L., Hichens, M. \& Macdonald, G.J. (1978) Effect of hypophysectomy, prolactin and prostaglandin F2 on gonadotropin binding in vivo and in vitro with corpus luteum. Endocrinology 103, 349-357.

Bennink, H.J. (1979) Intermittent bromocriptine treatment for the induction of ovulation in hyperprolactinaemic patients. Fert. Steril. 31, 267-272.

Besser, G.M., Parke, L., Edwards, C.R.W., Forsyth, I.A. \& McNeilly, A.S. (1972) Galactorrhoea: successful treatment with reduction of plasma prolactin levels by bromorgocryptine. Br. med. J. 3, 267-269.

Billeter, E. \& Fluckiger, E. (1971) Evidence for a luteolytic function of prolactin in the intact cyclic rat using 2-Br- $\alpha$-ergokryptine (CB154). Experientia 27, 464-465.

Bohnet, H.G., Shiu, R.P.C., Grinwich, D. \& Friesen, H.G. (1978) In vivo effects of antisera to prolactin receptors in female rats. Endocrinology 102, 16571661.

Caro, J.F. \& Woolf, P.D. (1980) Pituitary-ovarian axis responsivity to prolonged gonadotropin-releasing hormone infusion in normal and hyperprolactinaemic women. J. clin. Endocr. Metab. 50, 9991004.

Carruthers, T.D. \& Hafs, H.D. (1980) Suckling and four times daily milking: influence on ovulation, estrus and serum luteinizing hormone, glucocorticoids and prolactin in postpartum Holsteins. J. Anim. Sci. 50, 919-925.

Cowie, A.T., Forsyth, I.A. \& Hart, I.C. (1980) Hormonal Control of Lactation. Springer-Verlag, Berlin. 
Delvoye, P., Badawi, M., Damaegd, M. \& Robyn, C. (1978) Serum prolactin, gonadotropins and estradiol in menstruating and amenorrheic women during two years of lactation. Am. J. Obstet. Gynec. 130, 635-640.

Denamur, R., Martinet, J. \& Short, R.V. (1973) Pituitary control of the ovine corpus luteum. J. Reprod. Fert. 32. 207-216.

Diekman, M.A., O'Callaghan, P., Nett, T.M. \& Niswender, G.D. (1978) Validation of methods and quantification of luteal receptors for $\mathbf{L H}$ throughout the estrous cycle and early pregnancy in ewes. Biol. Reprod. 19, 999-1009.

Dominic, C.J. (1966) Effects of single ectopic grafts on the oestrous cycle of the intact mouse. $J$. Reprod. Fert. 12, 533-538.

Dorrington, J. \& Gore-Langton, R.E. (1981) Prolactin inhibits oestrogen synthesis in the ovary. Nature, Lond. 290, 600-602.

Duchen, M.R. \& MeNeilly, A.S. (1980) Hyperprolactinaemia and long-term lactational amenorrhoea. Clin. Endocr. 12, 621-627.

Eckstein, B. \& Nimrod, A. (1979) Effect of human chorionic gonadotropin and prolactin on $20 \mathrm{a}-$ hydroxysteroid dehydrogenase activity in granulosa cells of immature rat ovary. Endocrinology 104, 711-714.

Everett, J.W. (1961) The mammalian female reproductive cycle and its controlling mechanisms. In Sex and Internal Secretions, Vol. 1, pp. 497-555. Ed. W.C. Young. Williams \& Wilkins, Baltimore.

Fitzgerald, B.P. \& Cunningham, F.J. (1981) Effect of removal of lambs or treatment with bromocriptine on plasma concentrations of prolactin and FSH during the post-partum period in ewes lambing at different times during the breeding season. J. Reprod. Fert. 61, 141-148.

Fleming, R., Craig, A., England, P., Macnaughton, M.C. \& Coutts, J.R.T. (1978) Influence of hyperprolactinaemia on ovarian function in infertile women with normal menstrual rhythm. J. Endocr. 77, $14 P-15 P$, Abstr.

Fraser, I.S., Markham, R. \& Shearman, R.P. (1978) Plasma prolactin levels and ovarian responsiveness to exogenous gonadotropins. Obstet. Gynec., N.Y. $51,548-551$.

Garris, D.R. \& Rothchild, I. (1980) Temporal aspects of the involvement of the uterus and prolactin in the establishment of luteinizing hormone-dependent progesterone secretion in the rat. Endocrinology 107, 1112-1116.

Gibori, G. \& Richards, J.S. (1978) Dissociation of two distinct luteotrophic effects of prolactin: regulation of luteinizing hormone-receptor content and progesterone secretion during pregnancy. Endocrinology 102, 767-774.

Gibori, G., Richards, J.S. \& Keyes, P.L. (1979) Synergistic effects of prolactin and estradiol in the luteotropic process in the pregnant rat: regulation of estradiol receptors by prolactin. Biol. Reprod. 21, 419-423.

Glass, M.R., Rudd, B.T., Lynch, S.S. \& Butt, W.R. (1981) Oestrogen-gonadotropin feedback mechanisms in the puerperium. Clin. Endocr. 14, 257267.
Grandison, L. \& Meites, J. (1972) Luteolytic action of prolactin during the estrous cycle of the mouse. Proc. Soc. exp. Biol. Med. 140, 323-329.

Grinwich, D., Hichens, M. \& Behrman, H.R. (1976) Control of the $\mathrm{LH}$ receptor by prolactin and prostaglandin F $2 a$ in rat corpora lutea. Biol. Reprod. 14, 212-218.

Hammond, J.M. \& Krall, E. (1979) Steroid hormones modulate prolactin binding by cultured porcine granulosa cells. Biochem. Biophys. Res. Commun. 91, 284-288.

Hart, I.C. (1975) Seasonal factors affecting the release of prolactin in goats in response to milking. Endocrinology 64, 313-322.

Henderson, K.M., MeNeilly, A.S. \& Swanston, I.A. (1982) Gonadotrophin and steroid concentrations in bovine follicular fluid and their relationship to follicle size. J. Reprod. Fert. 65, 467-473.

Hilliard, J., Spies, H.G., Lucas, L. \& Sawyer, C.H. (1968) Effect of prolactin on progestin release and cholesterol storage by rabbit ovarian interstitium. Endocrinology 82, 122-131.

Hoffmann, B., Schams, D., Bopp, R., Ender, M.L., Gimenez, T. \& Karg, H. (1974) Luteotrophic factors in the cow: evidence for $\mathrm{LH}$ rather than prolactin. $J$. Reprod. Fert. 40, 77-85.

Holt, J.A., Richards, J.S., Midgley, A.R., Jr \& Reichert, L.E., Jr (1976) Effect of prolactin on LH receptor in rat luteal cells. Endocrinology 98, 1005-1013.

Howie, P.W. \& McNeilly, A.S. (1982) Effect of breast feeding patterns on human birth intervals. J. Reprod. Fert. 65, 545-557.

Jewelewicz, R., Dyrenfurth, J., Warren, M., Frantz, A.G. \& Vande Wiele, R.C. (1974) Effect of thyrotropinreleasing hormone (TRH) upon the menstrual cycle in women. J. clin. Endocr. Metab. 39, 387390.

Karsch, F.J., Cook, B., Ellicott, A.R., Foster, D.L., Jackson, G.L. \& Nazbandov, A.V. (1971) Failure of infused prolactin to prolong the life span of the corpus luteum in the ewe. Endocrinology 89, 272275.

Kemmann, E., Gemzell, C.A., Beinert, W.C., Belling, C.B. \& Jones, J.R. (1977) Plasma prolactin changes during the administration of menopausal gonadotropins in nonovulatory women. Am. J. Obstet. Gynec. 129, 145-149.

Klemcke, H.G. \& Brinkley, H.J. (1980) Endogenous rhythms of luteal and adrenal cholesterol ester hydrolase and serum PRL, LH and progesterone in mature pseudopregnant rats. Biol. Reprod. 22, 1022-1028.

Knobil, E., Plant, T.M., Wildt, L., Belchetz, P.E. \& Marshall, G. (1980) Control of the rhesus monkey menstrual cycle: permissive role of hypothalamic gonadotropin-releasing hormone. Science, N.Y. 207, 1371-1373.

Lachelin, G.C., Abufadil, L.S. \& Yen, S.S.C. (1978) Functional delineation of hyperprolactinaemic amenorrhoea. J. clin. Endocr. Metab. 44, 1163 1174.

Lamming, G.E. (1978) Reproduction during lactation. In Control of Ovulation, pp. 335-353. Eds D. B. Crighton, N. B. Haynes, G. R. Foxcroft \& G. E. Lamming. Butterworths, London. 
Lenton, E.A., Brook, L.M., Sobowale, O. \& Cooke, I.D. (1979) Prolactin concentrations in normal menstrual cycles and conception cycles. Clin. Endocr. 10, 383-391.

Louw, B.P., Lishman, A.W., Botha, W.A. \& Baumgartner, J.P. (1974) Failure to demonstrate a role for the acute release of prolactin at oestrus in the ewe. J. Reprod. Fert. 40, 455-458.

Malven, P.V. (1969) Luteotrophic and luteolytic responses to prolactin in hypophysectomized rats. Endocrinology 84, 1224-1229.

McGarrigle, H.H.G., Sarris, S., Little, V., Lawrence, D., Radwanska, E. \& Swyer, G.I.M. (1978) Induction of ovulation with clomiphene and human chorionic gonadotrophin in women with hyperprolactinaemic amenorrhoea. Br. J. Obstet. Gynaec. 85, 692697.

McNatty, K.P. (1977) Prolactin and ovarian steroidogenesis. Acta endocr., Copenh. 87, Suppl. 212, Abstr. 521.

MeNatty, K.P. (1979) Relationship between plasma prolactin and the endocrine microenvironment of the developing human antral follicle. Fert. Steril. 32 , 433-438.

McNatty, K.P., Sawers, R.S. \& McNeilly, A.S. (1974) A possible role for prolactin in control of steroid secretion by the human Graafian follicle. Nature, Lond. 250, 635-655.

McNatty, K.P., Bennie, J.G., Hunter, W.M. \& McNeilly, A.S. (1975) Antibodies to gonadotrophins and the subsequent rate of progesterone secretion by human granulosa cells in vitro. Clin. Exp. Immunoreprod. 3, 41-66.

McNatty, K.P., Neal, P. \& Baker, T.G. (1976) Effect of prolactin on the production of progesterone by mouse ovaries in vitro. J. Reprod. Fert. 47, 155-156.

McNeilly, A.S. (1979) Effects of lactation on fertility. Br. med. Bull. 35, 151-154.

McNeilly, A.S. (1980a) Prolactin and the control of gonadotrophin secretion in the female. J. Reprod. Fert. 58, 537-549.

McNeilly, A.S. (1980b) Paradoxical prolactin. Nature, Lond. 184, 212.

McNeilly, A.S. \& Baird, D.T. (1977) Influence of hyperprolactinaemia on pulsatile LH and ovarian oestradiol secretion during follicular phase of the sheep oestrous cycle. J. Steroid Biochem. 8, xii, Abstr.

McNeilly, A.S., Howie, P.W. \& Houston, M.J. (1980a) Relationship of feeding patterns, prolactin and resumption of ovulation post-partum. In Research Frontiers in Fertility Regulation, pp. 102-116. Eds G. I. Zatuchni, M. H. Labbok \& J. J. Sciarra. Harper \& Row, Mexico City.

McNeilly, A.S., O'Connell, M. \& Baird, D.T. (1980b) Induction of ovulation by pulsatile injections of $\mathrm{LH}$ in anoestrous ewes. Biol. Reprod. 22, (Suppl. 1) 48A, Abstr. 55.

McNeilly, A.S., Abbott, D.H., Lunn, S.F., Chambers, P.C. \& Hearn, J.P. (1981) Plasma prolactin concentrations during the ovarian cycle and lactation and their relationship to return of fertility post partum in the common marmoset (Callithrix jacchus). J. Reprod. Fert. 62, 353-360.

Muhlenstedt, D., Wuttke, W. \& Schneider, H.P.G.
(1977) Prolactin and short luteal phase infertility. Acta endocr., Copenh. 84, Suppl. 208, 43, Abstr.

Murphy, B.D. (1979) The role of prolactin in implantation and luteal maintenance in the ferret. Biol. Reprod. 21, 517-521.

Niswender, G.D. (1974) Influence of 2-br- $\alpha$-ergocryptine on serum levels of prolactin and the estrous cycle in sheep. Endocrinology 94, 612-615.

Nolin, J.M. (1980) Incorporation of endogenous prolactin by granulosa cells and dictyate oocytes in the postpartum rat: effects of estrogen. Biol. Reprod. 22, $417-422$.

Peters, A.R., Vyvoda, S. \& Lamming, G.E. (1979) Comparison of plasma prolactin levels in the milked and suckling cow. J. Endocr. 83, 27P-28P, Abstr.

Polatti, E., Bolis, P.F., Ravagni-Probizer, M.F., Baruffini, A. \& Cavelleri, A. (1978) Treatment of hyperprolactinaemic amenorrhea by intermittent administration of bromocriptine (CB154). Am. J. Obstet. Gynec. 131, 792-796.

Rao, M.C., Richards, J.S., Midgley, A.R., Jr \& Reichert, L.E., Jr (1977) Regulation of gonadotropin receptors by luteinizing hormone in granulosa cells. Endocrinology 101, 512-532.

Rhind, S.M., Robinson, J.J., Chesworth, J.N. \& Crofts, R.M.J. (1980) Effects of season, lactation and phase of nutrition on prolactin concentrations in ovine plasma and the role of prolactin in the control of ewe fertility. J. Reprod. Fert. 58, 145-152.

Richards, J.S. (1980) Maturation of ovarian follicles: actions and interactions of pituitary and ovarian hormones on follicular cell differentiation. Physiol. Rev. 60, 51-89.

Richards, J.S. \& Midgley, A.R. (1976) Protein hormone action: a key to understanding ovarian follicular and luteal cell development. Biol. Reprod. 14, 82-94.

Richards, J.S. \& Williams, J.J. (1976) Luteal cell receptor content for prolactin (PRL) and luteinizing hormone (LH): regulation by $\mathrm{LH}$ and PRL. Endocrinology 99, 1571-1581.

Richards, J.S., Ireland, J.J., Rao, M.C., Bernath, G.A., Midgley, A.R., Jr \& Reichert, L.E., Jr (1976) Ovarian follicular development in the rat: hormone receptor regulation by estradiol, follicle stimulating hormone and luteinizing hormone. Endocrinology 99 , 1562-1570.

Robyn, C., Delvoye, P., Van Exter, C., Vekmans, M., Caufriez, A., De Nayer, P., Delogne-Desnoeck, J. \& L'Hermite, M. (1976) Physiological and pharmacological factors influencing prolactin secretion and their relation to human reproduction. In Prolactin and Human Reproduction, pp. 71-96. Eds P. G. Crosignani \& C. Robyn. Academic Press, New York.

Rolland, R. \& Hammond, J.M. (1975) Demonstration of a specific receptor for prolactin in porcine granulosa cells. Endocr. Res. Commun. 2, 281-298.

Sarris, S., Swyer, G.I.M., McGarrigle, H.H.G., Lawrence, D.M., Little, V. \& Lachelin, G.C.L. (1978) Prolactin and luteal insufficiency. Clin. Endocr. 9, 543-547.

Schams, D., Schallenberger, E., Manzer, Ch., Stangl, J., Zottmeser, K., Hoffmann, B. \& Karg, H. (1978) Profiles of LH, FSH and progesterone in postpartum dairy cows and their relationship to the 
commencement of cyclic function. Theriogenology 10, 453-468.

Schulz, K.D., Geiger, W., del Pozo, E., Lose, K.H. Kunzig, H.J. \& Lancranjan, I. (1976) An influence of prolactin-inhibitor Bromocriptin (CB154) on human luteal function in vivo. Arch. Gynak. 221, 93-97.

Seppala, M., Hirvonen, E. \& Ranta, T. (1976) Hyperprolactinaemia and luteal insufficiency. Lancet $\mathbf{i}$, 229-230.

Smith, M.S., Freeman, M.E. \& Neill, J.D. (1975) The control of progesterone secretion during the estrous cycle and early pseudopregnancy in the rat: prolactin, gonadotrophin and steroid levels associated with rescue of the corpus luteum of pseudopregnancy. Endocrinology 96, 219-226.

Smith, V.R., McShaw, T.H. \& Casida, L.E. (1957) On maintenance of the corpora lutea of the bovine with lactogen. J. Dairy Sci. 40, 443-446.

Stevenson, J.S. \& Britt, J.H. (1979) Relationships among luteinizing hormone estradiol, progesterone, glucocorticoids, milk yield, body weight and postpartum ovarian activity in Holstein cows. J. Anim. Sci. 48, 570-577.

Stevenson, J.S., Cox, N.M. \& Britt, J.H. (1981) Role of the ovary in controlling luteinizing hormone, follicle stimulating hormone and prolactin secretion during and after lactation in the pig. Biol. Reprod. 24, 341-353.

Tyndale-Biscoe, C.H. (1979) Hormonal control of embryonic diapause and reactivation in the tammar wallaby. In Maternal Recognition of Pregnancy (Ciba Fdn Symp. No. 64 (new series)), pp. 173-190. Excerpta Medica, Amsterdam.

Tyndale-Biscoe, C.H. \& Hawkins, J. (1977) The corpora lutea of marsupials: aspects of function and control. In Reproduction and Evolution, pp. 245-252. Eds J. H. Calaby \& C. H. Tyndale-Biscoe. Australian Academy of Science, Canberra.

Veldhuis, J.D. \& Hammond, J.M. (1980) Oestrogens regulate divergent effects of prolactin in the ovary. Nature, Lond. 284, 262-264.
Veldhuis, J.D., Klase, P. \& Hammond, J.M. (1980) Divergent effects of prolactin upon steroidogenesis by porcine granulosa cells in vitro: influence of cyto differentiation. Endocrinology 107, 42-46.

Veldhuis, J.D., Klase, P.A. \& Hammond, J.M. (1981) Sex steroids modulate prolactin action in spontaneously luteinizing porcine granulosa cells in vitro. Endocrinology 108, 1463-1468.

Walton, J.S., MeNeilly, J.R., McNeilly, A.S. \& Cunningham, F.J. (1977) Changes in concentrations of follicle-stimulating hormone, luteinizing hormone, prolactin and progesterone in the plasma of ewes during the transition from anoestrus to breeding activity. $J$. Endocr. 75, 127-136.

Wang, C., Hsueh, A.J.W. \& Erickson, G.F. (1979) Induction of functional prolactin receptors by follicle stimulating hormone in rat granulosa cells in vivo and in vitro. J. biol. Chem. 254, 1330-1336.

Wang, C., Hsueh, A.J.W. \& Erickson, G.F. (1980) Prolactin inhibition of estrogen production by cultured rat granulosa cells. Molec. cell. Endocr. 20, $135-144$.

Webb, R., Lamming, G.E., Haynes, N.B. \& Foxcroft, G.R. (1980) Plasma progesterone and gonadotrophin concentrations and ovarian activity in postpartum dairy cows. J. Reprod. Fert. 59, 133143.

Wiest, W.G., Kidwell, W.R. \& Balogh, K., Jr (1968) Progesterone catabolism in the rat ovary: a regulatory mechanism for progestational potency during pregnancy. Endocrinology 82, 844859.

Wright, P.J., Geytenbeck, P.E., Clarke, I.J. \& Findlay, J.K. (1981) Evidence for a change in oestradiol negative feedback and LH pulse frequency in post-partum ewes. J. Reprod. Fert. 61, 97102.

Wuttke, W. \& Dohler, K.D. (1973) Partial and total blockade of pituitary prolactin release in rats: effects on pregnancy and serum progesterone. In Human Prolactin, pp.156-159. Eds J. L. Pasteels \& C. Robyn. Excerpta Medica, Amsterdam. 